\title{
Instabilities Susceptibility Assessment of Fractured Rock Masses Using Geographic Information System: Application on the Sector of Mako (South-Eastern Senegal)
}

\author{
Déthié Sarr¹, Hamath Kebe1, Hideaki Yasuhara², Ababacar Fall ${ }^{3}$, Mapathé Ndiaye1 \\ ${ }^{1}$ Laboratoire de Mécanique et Modélisation des terrain, UFR Sciences de l'Ingénieur, Université de Thiès, Thiès, Senegal \\ ${ }^{2}$ Department of Engineering, Ehime University, Matsuyama, Japan \\ ${ }^{3}$ Laboratoire des Sciences et Techniques de l'eau et de l'environnement (LaSTEE), Ecole polytechnique de Thiès, Thiès, Senegal \\ Email: dethie.sarr@univ-thies.sn
}

How to cite this paper: Sarr, D., Kebe, H., Yasuhara, H., Fall, A. and Ndiaye, M. (2019) Instabilities Susceptibility Assessment of Fractured Rock Masses Using Geographic Information System: Application on the Sector of Mako (South-Eastern Senegal). International Journal of Geosciences, 10, 995-1007.

https://doi.org/10.4236/ijg.2019.1011057

Received: October 3, 2019

Accepted: November 19, 2019

Published: November 22, 2019

Copyright $\odot 2019$ by author(s) and Scientific Research Publishing Inc. This work is licensed under the Creative Commons Attribution International License (CC BY 4.0).

http://creativecommons.org/licenses/by/4.0/

\section{(c) (i) Open Access}

\begin{abstract}
The Mako area located in the region of Kedougou is characterized by very hilly terrains with hardly accessible zones. This situation makes it difficult to map these terrains and exposes the populations to the permanent risk of a rock slide. The issue of this paper is to evaluate the instabilities susceptibility at the Mako zone located at the hilliest zone of Senegal. It is done using Geographic Information Systems (GIS). The predisposing factors that are slope, lithology, hydrography, fracturing, land use are defined by the GIS and field data then are confirmed by field observations. According to field observations, more possible scenarios are SC1 and SC4 at the dry season and rainy season respectively. The instabilities susceptibility maps are taken from weighted overlay of these factors and they show that hilly areas are the most susceptible to rockslide or landslide when fractures are present with percent of moderate to high susceptibility between $13 \%$ and $22 \%$. These percentages increase and can reach more than $40 \%$ with an intense water flow during the rainy season. Hazard can reach up to two hundred meters of foothill according to maps.
\end{abstract}

\section{Keywords}

Rockslide, landslide, Susceptibility, Predisposing Factor, GIS, Mako

\section{Introduction}

South-East Senegal is marked by the presence of a multitude of vulnerable zones 
to structural instabilities. This region, essentially constituted by Paleoproterozoic formations, is characterized, in addition to particular climatic conditions, by the presence of discontinuities in rock masses. The locality of Mako presents geomorphological conditions (particular topography), hydro-climatic (interannual and seasonal climatic variations, frequent heavy rains) and socio-economic (rural context, savage mining) ones, which lead to its terrain's instability. This very area has been the subject of previous works focusing on petrographic and geochemical aspects [1]-[5] and participated in knowledge the Kédougou-Kéniéba inlier. Geomechanical works are also done on essentially basaltic rock masses [6] [7] [8]. Even if access is often difficult, it is necessary to understand the behaviour of other rock masses. Because of the mining boom and possible demographic growth, it is important to identify the hazard area.

The hazard cartography of rockslide provides valuable information for planning [9] [10]. They are considered by many specialists as the basis of any effective prevention and factors taken into account depending on the purpose of authors [11] [12] [13] and the observation made in the field. The indirect mapping methods enable the indication of potentially unstable zones on the basis of geological observations, geomorphology, topography and land use in the south part of Mako. This kind of studies are done by authors to define lineament of a site [14], characterizing water table in a sector, or combining various factors for a landslide [15] in the soft sedimentary area or another case study. Factors taken on account depend on these works. For rock masses, slide and rubble movements happen when the force of gravity exceeds the forces that stabilize the slope [9]. Rock formations behaviour depends on their mineralogy which has an impact on physico-mechanical alteration processes. Fractures play a major role because they are weak plans and higher permeability than rock matrix. The action of watercourse [12] caused erosion and weakness of rock and fractures. The presence of the vegetation stabilizes the rock masses and allows water absorption by roots and therefore improves their resistance to shear. It reduces surface erosion due to water flow. The main purpose of this paper, if we take the locality of Mako as the target, consists of mapping the hazard rockslide and landslide of this sector which will permit to establish of its susceptibility map. This work started by the mapping of predisposing factors that can influence stabilities. A model based on the development of the GIS tool is used to analyse the different factors contributing to the triggering of rockslides such as slope, geology, fracturing, water system, and land uses. Susceptible hazard areas are evaluated by overlaying these factors under ArcGIS. Because this area is composed essentially by hard rocks, hilly areas should be more susceptible when rock masses are fractured.

\section{Material and Method}

\subsection{Study Area}

The study area belongs to the Mako supergroup in the Kédougou-Kéniéba inlier. It is located between the latitudes $12^{\circ} 24$ and $12^{\circ} 18 \mathrm{~N}$ and the longitudes $12^{\circ} 54$ and $12^{\circ} 48 \mathrm{~W}$ in the administrative region of Kédougou (Figure 1). It is a very 


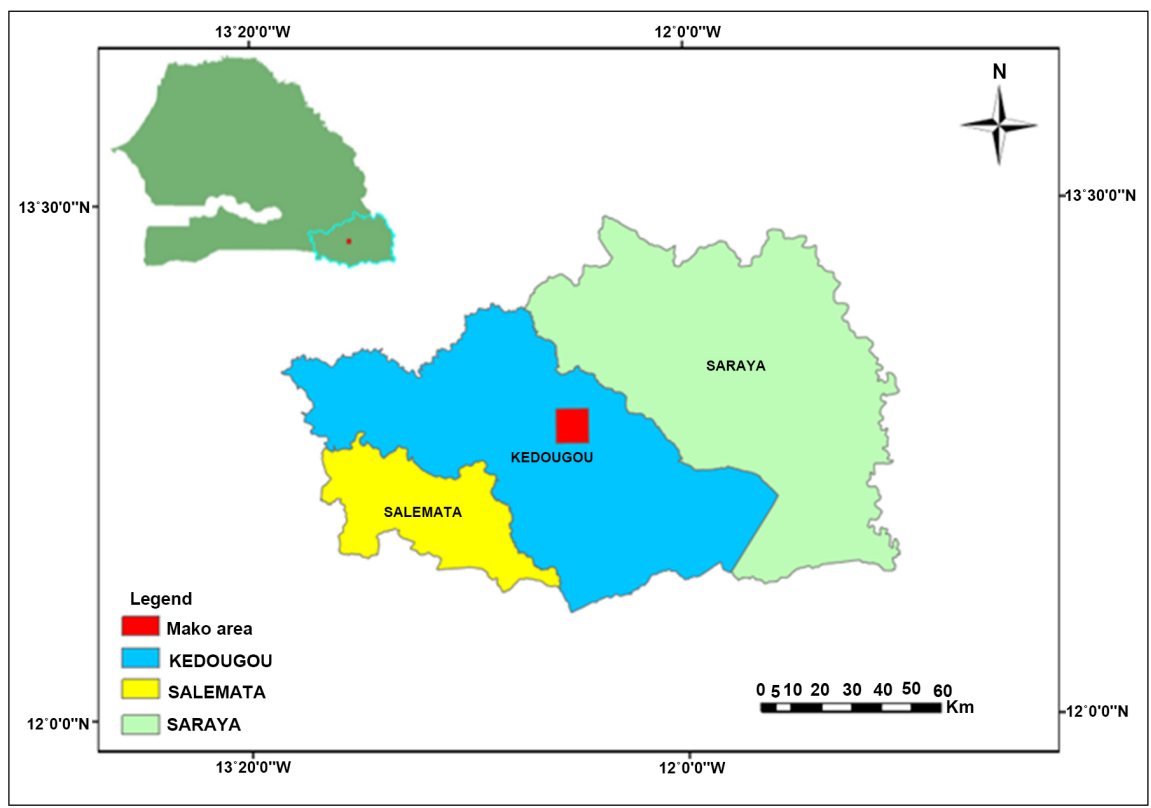

Figure 1. Location of mako at the region of kédougou (Senegal).

hilly zone with very steep slopes (steeper than $30^{\circ}$ ) and peaking to more than $200 \mathrm{~m}$. It is crossed by the River Gambia giving it a dense network of streams).

The geological studies that have been conducted in the area of Mako [1]-[7], enabled the identification of various facies:

- Meta basalts flow distributed geographically according to their structure, with pillow metabasalts flow in the west, and solidly structured meta basalts flows in the eastern areas;

- Peridotites located between the two facies of metabasalt;

- A more discrete acid volcanism represented by weak rhyodacites flows due to the abundance of pyroclastics;

- We also have in the East of Mako andesitic volcanism;

- Meta sediments composed of fine and coarse structured volcanic rocks widespread in the eastern part of the area;

- Two sorts of granitoids: the Granit of Soukourtou which dominant facies is a deformed gneissic aspect granodiorit, and the granit of Soukouta which long axis is positioned N-S and associated with rhyodacites at its edges.

These facies are grouped in five classes in this study (Figure 2). In a tectonic point of view, we find different structures in the form of shear zones with regional extension and faults along which there are quartz seams or felsitic rocks. These structures are oriented NW to NNW in the western parts and NNE to NE in the eastern ones.

\subsection{Methodological Approach}

The cartography of landslide requires an evaluation of the hazard level [11], defined by an intensity and a spatial and temporal probability occurrence that 


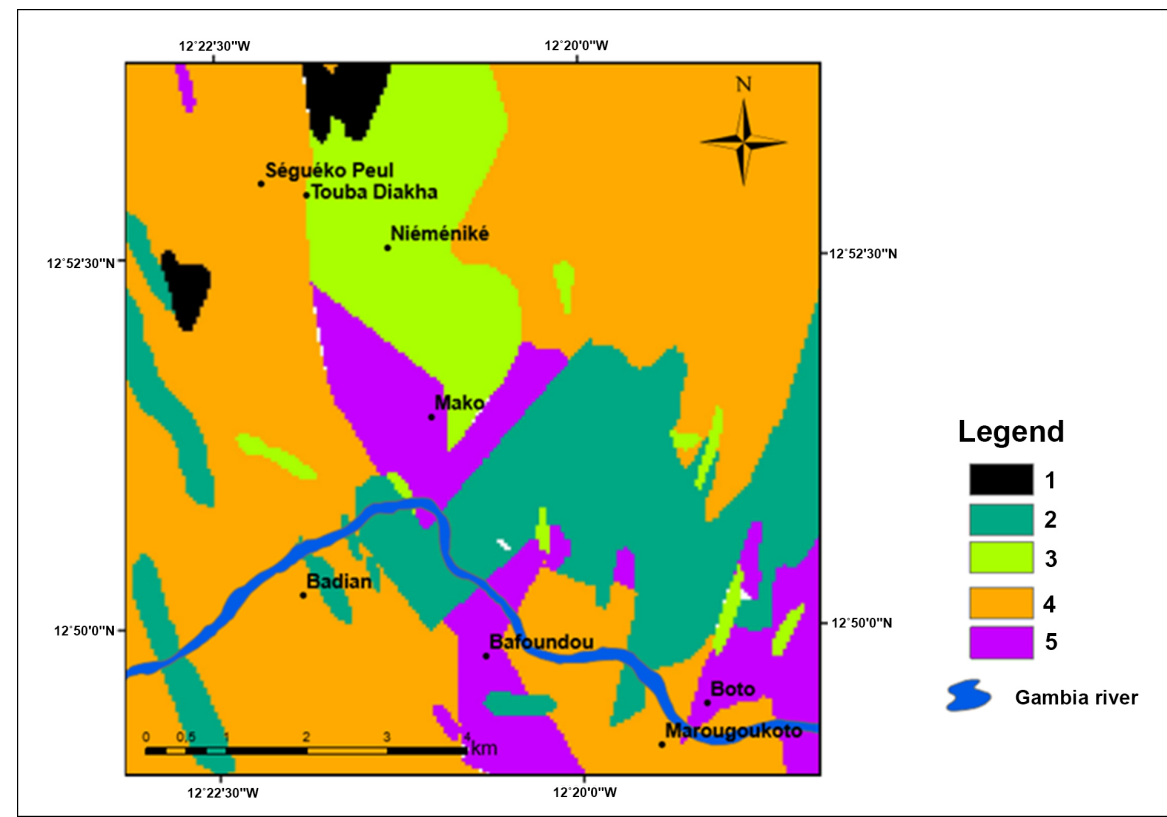

Figure 2. Mako's lithologic map (1. F1; 2. F2; 3. F3; 4. F4; 5. F5). F1 (acid plutonic rock facies: granite); F2 (basic and ultra-basic plutonic rocks: metagabbros and peridotites); F3 (rhyolite, microgranite/dacite, meta andesite); F4 (basic volcanic rock: metabasalt); F5 (volcano sediments and sedimentary rocks: volcano-detritic rocks, pyroclastics and quartzites).

depends on predisposing and trigger factors. However, so far as it is actually difficult to measure a hazard level, only landslide susceptibility to a sort of phenomenon is analyzed through this research work. Indeed, the necessary data for a complete and rigorous hazard analysis, as well as those regarding the trigger factors are not always available or sufficiently detailed [15] [16]. The techniques of spatial analysis specially, enable the evaluation of landslide susceptibility, based on two approaches [10]: a direct approach and an indirect one. The indirect approach is used by some authors [17] [18] when monitoring data are available.

The quantitative estimate of instabilities susceptibility, as well as its spatial distribution in the sector of Mako, is conducted in this work by applying a punctual empirical model. That kind of study was conducted by Wachal and Hudak [16] which are different from this work by the predisposing factors that are used and the hardness of rocks. The combination of index maps requires input data of spatialized elements that characterize factors leading to rock and landslide triggering. This approach is based on the cartography of factors considered as the most influential on rock stability which are slope, lithology, hydrography, fracturing and land use. If we consider the former studies and observations in the field, these five factors will be used for the cartography of instabilities susceptibility of Mako's area. These factors have been evaluated and shaped in a GIS from an existing spatial databases, and information digitalization coming from topographic and geological maps and satellite images processing (Figure 3). The slope mapping is conducted under ArcGIS from a DEM 


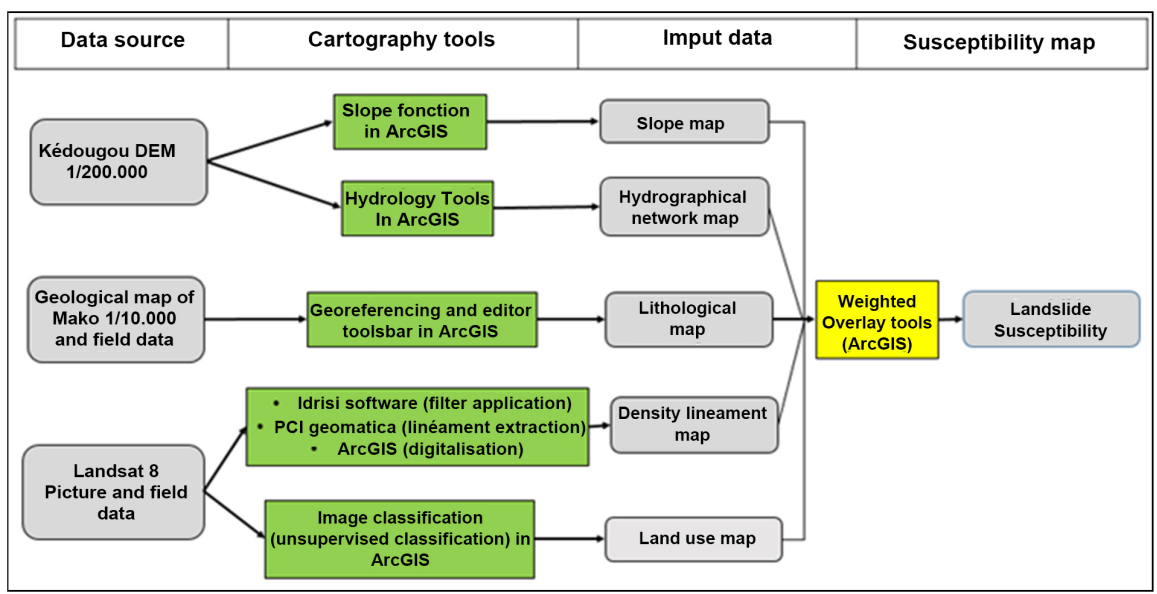

Figure 3. Structure of the successive stages to conduct the land movement hazard zoning thanks to GIS.

(Digital Elevation Model) on the scale 1/200,000 of the region of Kedougou. The lithology is extracted by the digitalization of the geological map of eastern Senegal on the scale 1/10,000. All rock facies and discontinuities are identified and confirmed in the field. The discontinuities are obtained by lineaments automated extraction with the PCI GEOMATICA software from a Landsat 8 image with the use of a directional filter Sobel on Idrisi selva. Among detected lineaments, only those which orientations are confirmed in the field will be taken into account in this study. The hydrographic network has been extracted from the DEM of the region of Kedougou thanks to hydrology tools in arc tools box under ArcGIS. Note that in the model, only the distance in water is considered. The land use map can be obtained by the combination of information coming from images classification Landsat 8 and data collected in the field. All input data in Figure 3 are 1/10,000 scale. For each predisposing factor, field verification has been conducted to correlate terrain observation with input data of Figure 3. That permits to define factors which impact more instabilities.

Each factor is subdivided into five classes to which we assign a value between 1 and 5, with value 1 representing the less susceptible classes and value 5 the more susceptible ones (Table 1). On the basis of their influence on rockslide susceptibility, a percentage by weight between 0 and $100 \%$ is affected to each factor (the sum of weights being 100\%). The adopted approach is then based on the cartography of predisposing factors and their overlay. It is done in three steps. First, field investigation is done to characterize the lithological and structural composition of Mako. Then, predisposing factors map is made using GIS and field informations. Site verification is conducted to evaluate obtained triggering maps. At last, the overlay of triggering factors under ArcGIS is conducted to produce susceptibility maps. The conformity of these susceptibility maps is verified at the accessible area of the fields and generalized for the whole study area.

Four combinations (Table 1) are adopted in this work where we considered that fracturation and slope are the bigger roles based on the field conclusion. It 
Table 1. Factor's weighted for susceptibility calculations.

\begin{tabular}{|c|c|c|c|c|c|c|c|}
\hline \multirow{2}{*}{ Factors } & \multirow{2}{*}{ Characteristics } & \multirow{2}{*}{ Susceptibility } & \multirow{2}{*}{ Scale } & \multicolumn{4}{|c|}{ Weighted of Scenario (SC) } \\
\hline & & & & $\mathrm{SC} 1$ & $\mathrm{SC} 2$ & $\mathrm{SC} 3$ & $\mathrm{SC} 4$ \\
\hline \multirow{5}{*}{ Slope } & $0^{\circ}-5^{\circ}$ & Nil & 1 & \multirow{5}{*}{35} & \multirow{5}{*}{30} & \multirow{5}{*}{30} & \multirow{5}{*}{25} \\
\hline & $5-10$ & Low & 1 & & & & \\
\hline & $10-15$ & Moderate & 2 & & & & \\
\hline & $15-25$ & High & 3 & & & & \\
\hline & $>25^{\circ}$ & Very high & 5 & & & & \\
\hline \multirow{5}{*}{ Lythology } & $\begin{array}{l}\text { Acid and intermedaite } \\
\text { plutonic rock masses }\end{array}$ & Low & 1 & \multirow{5}{*}{20} & \multirow{5}{*}{20} & \multirow{5}{*}{20} & \multirow{5}{*}{20} \\
\hline & $\begin{array}{c}\text { Basic and ultrabasic } \\
\text { plutonic rocks }\end{array}$ & Low & 1 & & & & \\
\hline & $\begin{array}{l}\text { Rhyolite, microgranits/ } \\
\text { dacite, meta andesite }\end{array}$ & Moderate & 2 & & & & \\
\hline & Basic volcanic rocks & High & 2 & & & & \\
\hline & $\begin{array}{l}\text { Volcanosedimentary and } \\
\text { sedimentary rocks }\end{array}$ & high & 4 & & & & \\
\hline \multirow{5}{*}{ Fracturation } & Very dense & Very high & 5 & \multirow{5}{*}{30} & \multirow{5}{*}{35} & \multirow{5}{*}{25} & \multirow{5}{*}{30} \\
\hline & Dense & High & 4 & & & & \\
\hline & Moderate & Moderate & 3 & & & & \\
\hline & Low & Low & 2 & & & & \\
\hline & Very low & Nil & 1 & & & & \\
\hline \multirow{5}{*}{$\begin{array}{c}\text { Hydrographic } \\
\text { Network }\end{array}$} & $0-25$ & Very high & 5 & \multirow{5}{*}{0} & \multirow{5}{*}{0} & \multirow{5}{*}{15} & \multirow{5}{*}{15} \\
\hline & $25-50$ & High & 4 & & & & \\
\hline & $50-100$ & Moderate & 2 & & & & \\
\hline & $100-200$ & Low & 1 & & & & \\
\hline & $>200$ & Nil & 1 & & & & \\
\hline \multirow{5}{*}{ Land use } & Water expanse & Low & 1 & \multirow{5}{*}{15} & \multirow{5}{*}{15} & \multirow{5}{*}{10} & \multirow{5}{*}{10} \\
\hline & Dense vegetation & Low & 1 & & & & \\
\hline & Dense vegetation & Low to nil & 1 & & & & \\
\hline & Agricultural land & Moderate & 2 & & & & \\
\hline & Building and bare sol & High & 4 & & & & \\
\hline
\end{tabular}

consists of varying pondering the triggering factor taking account water system and during season (SC1, SC2, SC3 and SC4).

\section{Results and Discussions}

\subsection{Predisposing Factors of Landslide Mapping}

Lithology: The lithological map extracted by the digitalization of Mako's geological map under ArcGIS has been subdivided into five classes of facies (Figure 2). The class sensitivity for each type of facies has been attributed from 
petrographic properties of rocks and their sensitivity to failure which depends on rocks location.

The slope factor: Landslide is conditioned by the mass of involved materials but also by the slope gradient of the hills. Some studies have shown that the steep slopes are the most favourable to failure [9]. The slopes map obtained (Figure 4) has been subdivided into five slope classes (from 1 to 5). More susceptible class corresponds with the massifs with a slope steeper than $25^{\circ}$.

Fracturation: Tectonic conditions impact significantly rockslide susceptibility of rock masses. Fractures are supposed to have a mechanical resistance weaker than that of the rock. To consider the influence of fracturing in the analysis of landslides susceptibility, a fracturing map of the sector of Mako has been made from a scene Landsat 8 . This work has allowed us to establish the fracturing map of Mako (Figure 5(a)) which shows three families of discontinuities structuring the area of Mako. The N-S one corresponds with shear zones directions, the second direction represents the shear zones and kilometric extension faults oriented NNW in the western part and NNE in the eastern one, and the third one is composed of orientation accidents WNW and ENE of weak extensions. These results corroborate that of Sarr et al. [6] conclusion. The scale of fracturation is shown in fracturing density map (Figure $5(\mathrm{~b})$ ). The fracturing has been integrated into the analysis by determining its density by a unit of area. The hard rocks fracturing impact highly the instabilities at the Mako area.

The hydrographic factor: Surface runoff generates intensive gully zones in the case of soft rocks in geological formations and sliding belong discontinuities for hard rocks. That factor is considered in this work by the modelling of the

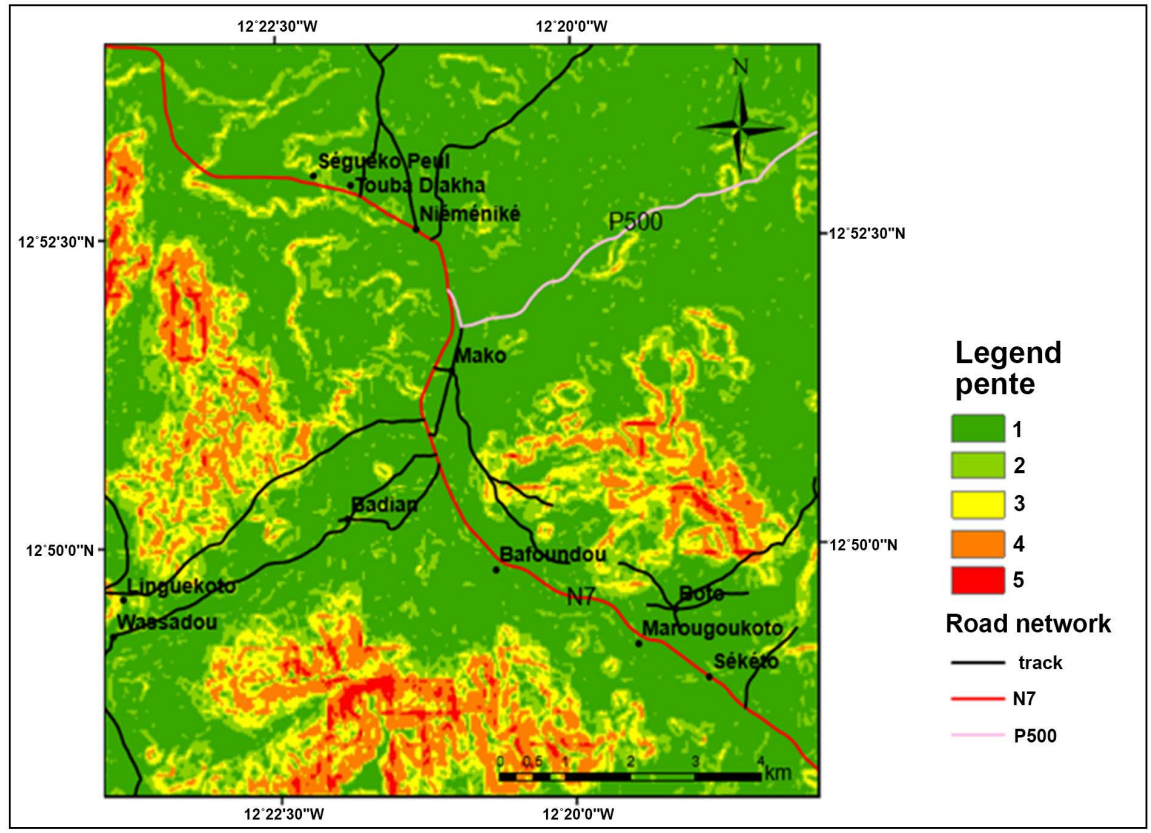

Figure 4. Mako's slopes map $\left(1\right.$. Slope $0^{\circ}-5^{\circ} ; 2$. Slope $5^{\circ}-10^{\circ}$; 3. Slope $10^{\circ}-15^{\circ} ; 4$. Slope $15^{\circ}-25^{\circ}$; 5 . Higher than $25^{\circ}$ ). 


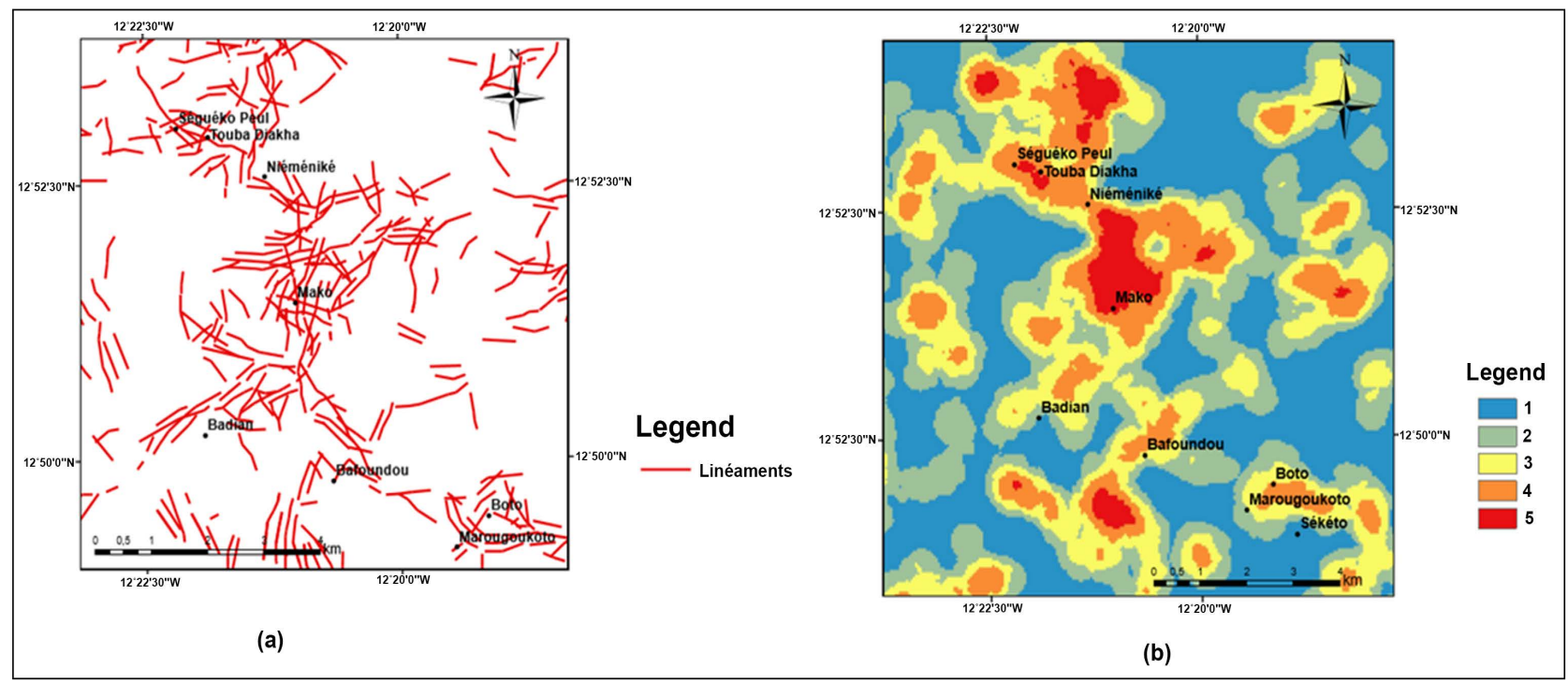

Figure 5. Fracturing maps of Mako ((a) fractures; (b) fracture's density (1. Very low fractured zone; 2. Low fractured zone; 3. Medium fractured zone; 4. High fractured zone; 5. Very high fractured zone)).

water drainage system of Mako. Under ArcGIS, we can extract the hydrographic network of a region from a DEM, thanks to spatial analysis of powerful functionalities. The different manipulations conducted on the DEM have allowed us to extract the hydrographic network of Mako (Figure 6(a)). However, in the model, we consider the impact of flow on the terrains by giving a greater susceptibility to those on which passes the network, by determining the distance in relation to this latter, thanks to the function "Euclidian distance" on ArcGIS (Figure 6(b)).

The land use factor: The land use map is obtained by the combination of information coming from a multispectral images classification of Landsat 8 scene thanks ArcGIS unsupervised image classification tool's and data collected in the field. Land use (Figure 7) plays an important role in terrains stability especially at the sloping surfaces level at Mako. Agriculture and urbanization tend to reduce terrains stability by creating weakness zones through the water flow regime change or increasing field stresses. Vegetation favours massif's stability.

\subsection{Rockslide and Landslides Susceptibility Maps}

The combination of these different factors maps thanks to the tool Weighted Overlay, gives the landslide susceptibility map in the locality of Mako (Figure 8). The function used enables the overlay of several rasters by using a common map scale and weigh them according to their importance on the studied phenomenon leading to the production of a thematic map. The level of natural hazard is identified by using results that we obtain after the superposition of predisposing factors of the landslide but also by taking into account the observations that we make in the study area concerning possibilities of landslides. Then three classes are identified: nil to low, moderate and high (Table 2). 


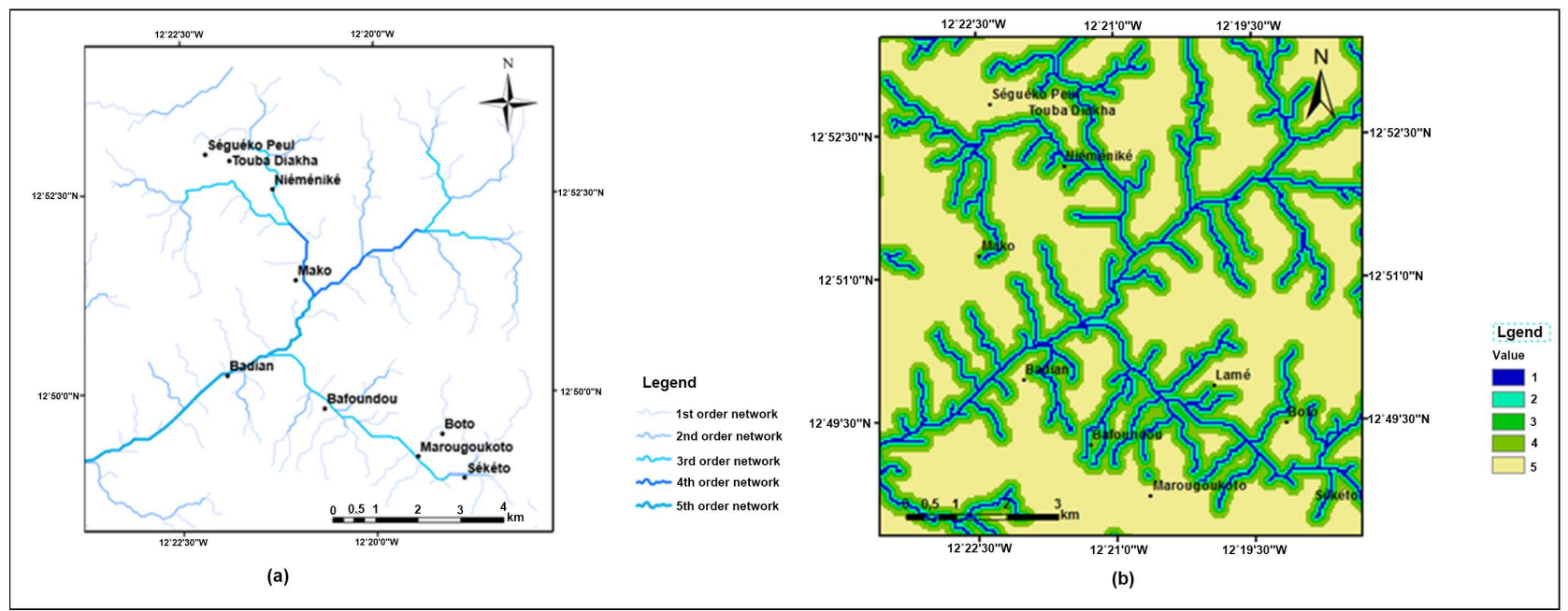

Figure 6. Mako's hydrographical maps ((a). hydrographical network; (b) distance in relation to water drainage systems (1. [0, 25]; 2. $[25,50] ; 3$. [50, 100]; 4. [100, 200]; 5. $\geq 200))$.

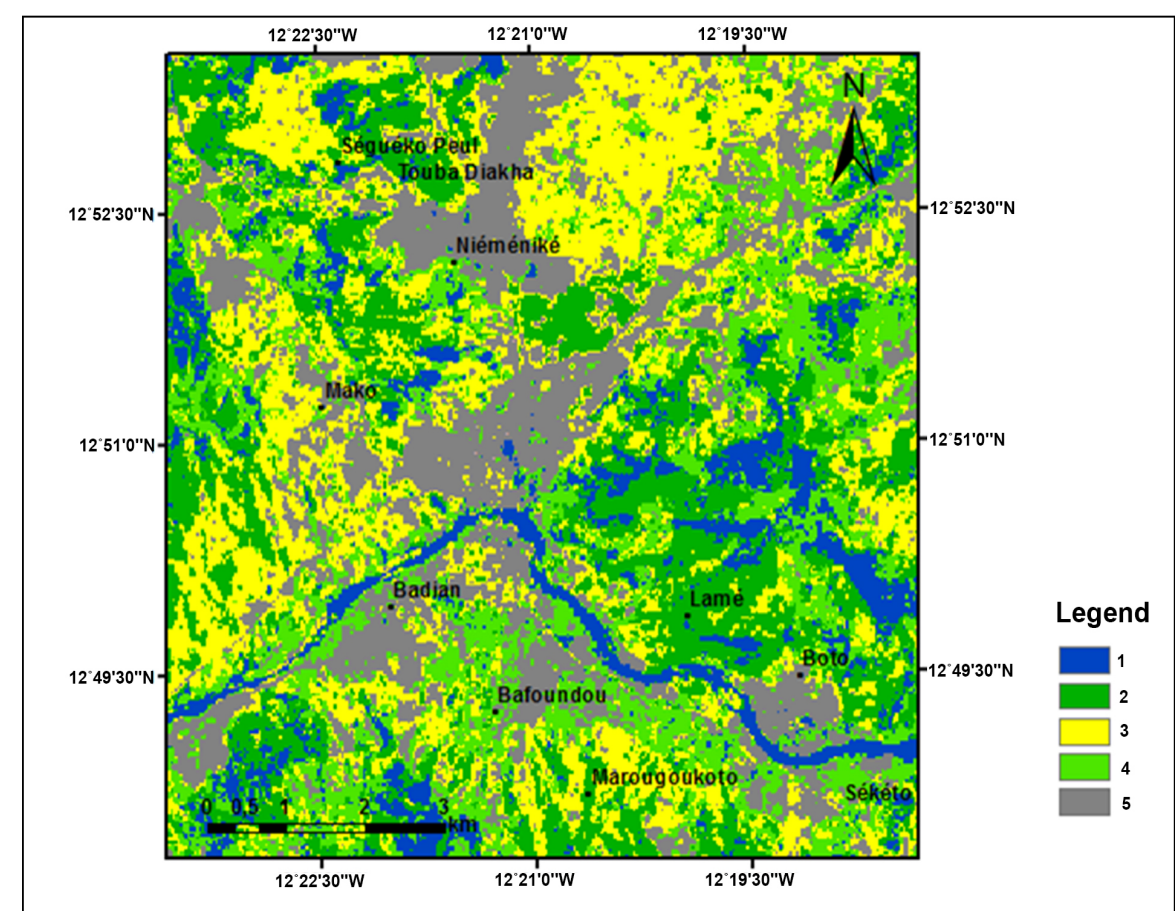

Figure 7. Land use map (1. Water bodies; 2. Dense vegetation; 3. Agricultural ground; 4. Vegetation; 5. Construction and bare floor).

Table 2. Percent area affected by Class Susceptibility for each Scenario SC.

\begin{tabular}{cccccc}
\hline \multirow{2}{*}{ Susceptibility class } & Natural hazard & \multicolumn{4}{c}{ Area of susceptibility vs. scenario SC (\%) } \\
\cline { 3 - 6 } & & SC1 & SC2 & SC3 & SC4 \\
\hline Class 1 & Nil to Low & 77.9 & 86.6 & 40.7 & 58.5 \\
Class 2 & Moderate & 16.9 & 11.7 & 51.7 & 32.2 \\
Class 3 & High & 5.1 & 1.7 & 7.6 & 9.3 \\
\hline
\end{tabular}


- The nil to low susceptibility class characterizes terrains that present any or low possibility of a landslide. The local environmental conditions (low slope gradient $0^{\circ}-10^{\circ}$, network fracturing and hydrographic network missing and presence of a vegetation more or less dense) favour rock stability. It corresponds also with flat land consisting of hard rocks. Slide occurs exceptionally during the rainy season.

- The moderate susceptibility class shows the moderate possibility of landslide triggering. The local environmental conditions (moderate slope gradient $\left(10^{\circ}\right.$ $-15^{\circ}$ ), and presence of a slope failure and escarpment due to fracturing) are favourable to landslides triggering. However, in these zones, we notice the presence of vegetation more or less dense and hard volcanic rocks that tend to improve those terrains' stability. Landslides rarely occur in these areas. They are essentially remarked during the rainy season.

- The high susceptibility class presents a strong possibility of landslide and/or rock slide triggering. The very high slope gradient of these zones as well as their very steep nature associated with their fracturing networks greatly and sometimes low quality rocks favour the triggering of landslides. It occurs at gully zones with soil or soft rocks and at steeper zones with high fractured rocks.

According to results, slopes play key roles in instabilities during the dry season where the action of water is minimal to nil (Figure 8(a) and Figure 8(b)). The percent of affected lands are defined in Table 2 above (SC1 and SC2). However, during the rainy season where water systems are active, discontinuities play the leading roles (Figure 8(c) and Figure 8(d)), since they constitute fluid circulation systems and weakness area of rocks. Thus, the interstitial overpressures bring about instabilities. The surface of instabilities susceptibility rate increases with the cracking, even if the role of the slope is determining (Table 2, SC3 and SC4). That explains the high susceptibility of moderate to low susceptibility zone with dense fracturing systems. Fields observations show that scenario SC1 and SC4 are more likely occurred in dry season and wet season respectively.

\section{Conclusion}

Instabilities in the sector of Mako result from the combination of different factors: the steepness of terrains, the density of fracturing, water drainage, land use and also the nature of rocks occupying the terrains. The weighted overlay of these factors using the GIS tool does show that they control the landslides susceptibility. This susceptibility is aggravated by the roughness of terrains including the presence of fractured rock masses organized in hills. The more exposed sites are somewhat with remarkable steepness, high fractured rock, and possible water flow. During the dry season where the action of water is minimal to nil, slopes play key roles in instabilities of fractured rock masses. However, during the rainy season where water systems are active, discontinuities play the leading roles, since they constitute fluid circulation systems. Thus, the 


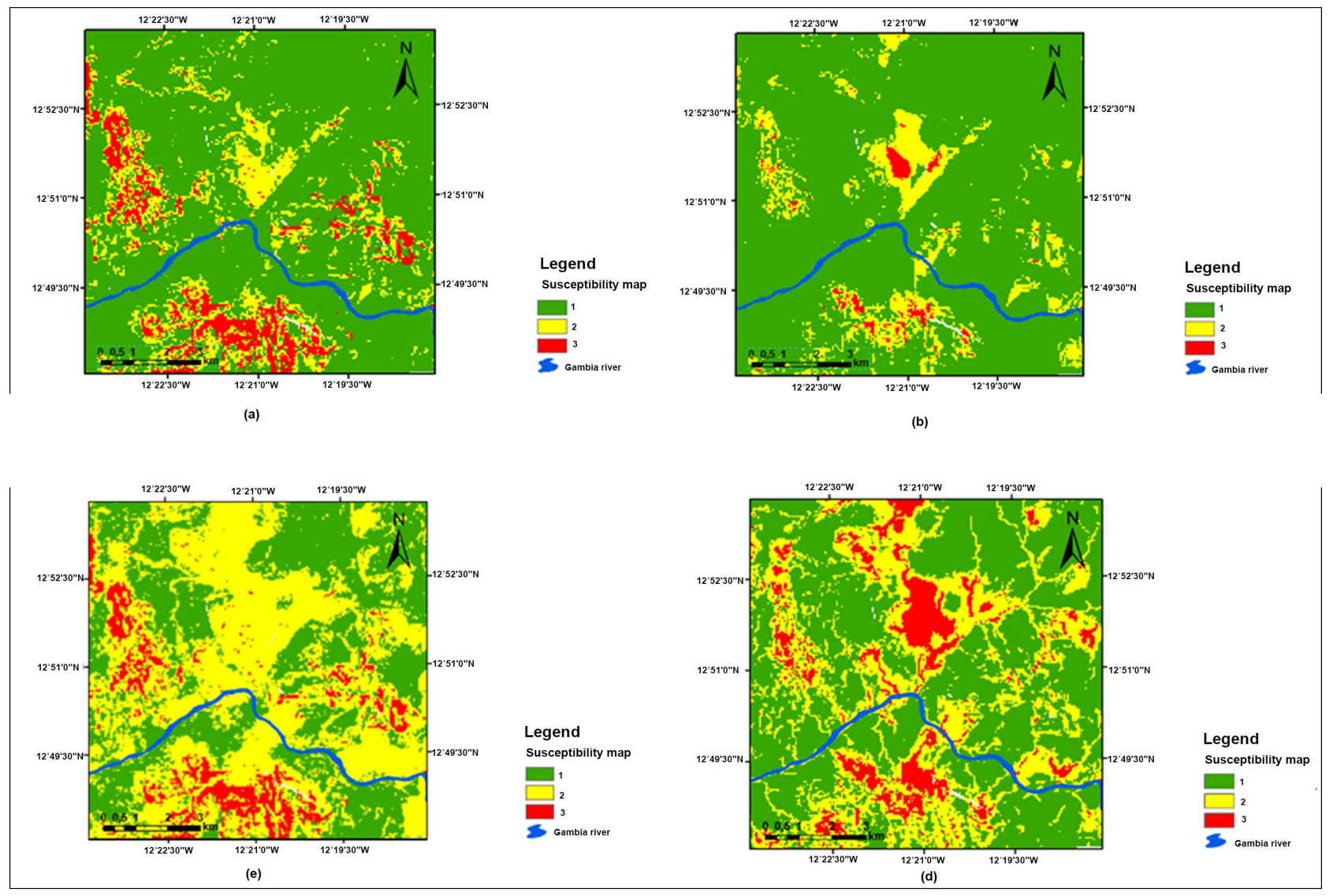

Figure 8. Map of instabilities susceptibility in the region of Mako ((a) scenario 1; (b) scenario 2; (c) scenario 3; (d) scenario 4 refer to Table 1).

interstitial overpressures bring about instabilities. The hydraulic properties impact also mineralogical alteration and dissolution of rock masses. The instabilities susceptibility rate increases with the failure and alteration, even if the role of the slope is determining. Even if the massifs seem stable according to their age, it is important to warn local people to hazard area where rock slide is possible above all during the rainy season. The hilly susceptible areas would be an object of rockfall studies to estimate danger for the local population and tourists.

\section{Acknowledgements}

Authors would acknowledge to Professor Papa Malick NGOM of University Cheikh Anta Diop of Dakar (UCAD) for his help in producing this work.

\section{Conflicts of Interest}

The authors declare no conflicts of interest regarding the publication of this paper.

\section{References}

[1] Ngom, P.M. (1995) Caractérisation de la croûte Birimienne dans les parties centrale et méridionale du supergroupe de Mako. Implications géochimiques et pétrogénétiques. 
Thèse d'Etat Université Cheikh Anta Diop de Dakar, Sénégal.

[2] Diallo, D.P. (1994) Caractérisation d'une portion de croûte d'âge protérozoïque inférieur du craton ouest africain: Cas de l'encaissant des granitoïdes dans le supergroup de Mako (Boutonnière de Kédougou). Implications géodynamiques. Thèse d'Etat. Université Cheikh Anta Diop de Dakar, Sénégal.

[3] Dia, A. (1988) caractères et signification des complexes magmatiques et métamorphiques du secteur de sandikounda laminia (nord de la boutonnière de Kédougou; est du Sénégal) un modèle géodynamique du Birimian de l'Afrique de l'ouest. Thèse d'Etat. Université Cheikh Anta Diop de Dakar, Sénégal.

[4] Cissokho, S. (2010) Etude géologique du secteur de Mako (partie méridionale du supergroupe de Mako, boutonnière de Kédougou Kéniéba, Sénégal oriental): Implication sur la diversité magmatique. Thèse de $3^{\mathrm{e}}$ cycle, Université Cheikh Anta Diop de Dakar, Sénégal.

[5] Delor, C., Couëffé, R., Goujou, J.C., Diallo, D.P., Théveniaut, H., Fullgraf, T., Ndiaye, P.M., Dioh, E., Blein, O., Barry, T.M.M., Cocherie, A., Le Métour, J., Martelet, G., Sergeev, S. and Wemmer, K. (2010) Notice explicative de la carte géologique à 1/200 000 du Sénégal, feuille Saraya-Kédougou Est. Ministère des Mines, de l'Industrie, de l'Agro-Industrie et des PME, Direction des Mines et de la Géologie, Dakar, 192 p.

[6] Sarr, D., Fall, M., Ngom, P.M. and Ndiaye, M. (2011) Mechanical Behavior of Pillow Lavas in Mako Supergroup: Case of South Mako Hill. International Journal of Géosciences, 4, 640-647. https://doi.org/10.4236/ijg.2011.24065

[7] Sarr, D. (2012) Propriétés géomécaniques des basaltes en pillow de Mako et des roches grésopélitique de Ségou (boutonnière de Kédougou-Kéniéba) au Sénégal. Thèse de Doctorat de l'Université Cheikh Anta Diop de Dakar (UCAD), Sénégal.

[8] Sarr, D., Fall, M., Sall, O.A., Ngom, P.M. and Berthaud, Y. (2018) Geotechnical Behavior of Eastern Senegal Rock Mass Slopes by Geomechanical Classifications and Applications. Journal of Geoscience and Environment Protection, 6, 11-24. https://doi.org/10.4236/gep.2018.65002

[9] Wachal, D.J. and Hudak, P.F. (2000) Mapping Landslide Susceptibility in Travis Country, Texas, USA. GeoJournal, 51, 245-253. https://doi.org/10.1023/A:1017524604463

[10] Malet, J.P., Thiery, Y., Maquaire, O. and Puissant, A. (2006) Analyse spatiale, évaluation et cartographie du risque glissement de terrain. Revue Internationale de Géomatique, Lavoisier, 16, 499-525. https://doi.org/10.3166/rig.16.499-525

[11] Thiery, Y., Malet, J.P., Sterlacchini, S., Puissant, A. and Maquaire, O. (2005) Analyse spatiale de la susceptibilité des versants aux glissements de terrain. Revue Internationale de Géomatique, Lavoisier, 15, 227-245.

[12] Aaggad, N.E., Algouti, A., Algouti, A. and Amaya, A. (2015) Cartographie par sig de l'aléa d'éboulement dans le bassin versant de dades (haut atlas central), Maroc. European Scientific of Journal, 11, 222-237.

[13] Alkinson, P.M. and Massari, R. (1998) Mapping Susceptibility to Landsliding in the Central Apennines, Italy. Computers and Geosciences, 24, 373-385. https://doi.org/10.1016/S0098-3004(97)00117-9

[14] Sedrette, S. and Rebai, N. (2016) Automatic Extraction of Lineaments from Landsat Etm+ Images and Their Structural Interpretation: Case Study in Nefza Region (North West of Tunisia). Journal of Research in Environmental and Earth Sciences, 4, 139-145.

[15] Ndoye, I., Ndiaye, M., Sarr, D., Faye, P.S. and Cissé, I.K. (2018) Cartography of 
Landslide Susceptibility around the Dias Horst and Thies Cliff-Senegal. International Journal of Geosciences, 8, 821-836.

https://doi.org/10.4236/ijg.2017.86047

[16] Thiery, Y. (2007) susceptibilité du bassin de Barcelonette (Alpes du sud, France) aux mouvements de versant; cartographie morphodynamique, analyse spatiale et modélisation probabiliste. Thèse de doctorat, Université de Caen, $445 \mathrm{p}$.

[17] Arca, D., Kutoglu, H.S. and Becek, K. (2018) Landslide Susceptibility Mapping in an Area of Underground Mining Using the Multicriteria Decision Analysis Method. Environmental Monitoring and Assessment, 190, 725.

https://doi.org/10.1007/s10661-018-7085-5

[18] Mergali, M., Schwarz, L. and Kociu, A. (2018) Combining Release and Runout in Statistical Landslide Susceptibility Modeling. Landslides, 1-15.

https://doi.org/10.1007/s10346-019-01222-7 